\title{
SUSTAINABLE CITY PLANNING: EMPHASIS ON THE MANAGEMENT OF ENVIRONMENTALLY SENSITIVE AREAS ${ }^{1}$
}

\author{
Halimaton Saadiah Hashim ${ }^{2}$, \\ Joy Jacqueline Pereira \& Ibrahim Komoo \\ Institute for Environment and Development (LESTARI) \\ UNIVERSITY KEBANGSAAN MALAYSIA
}

\section{Abstract}

The need to identify and manage environmentally sensitive areas (ESAs) is of fundamental importance for seeking balanced development within and around such areas based on the concept of sustainable development. The identification of ESAs enhances the understanding of the various trade-offs between land development, environmental protection and societal well-being, and this facilitates effective planning for future development. The concept of ESAs, which evolved from a sectoral approach at the international and national levels, was modified to be more integrated for its implementation at the city and state levels, even at national levels. The Selangor State Policy on ESA was officially launched on 5 June 1999. The Policy takes into account the importance of an area from the perspective of the implementing government agencies and the perspective of its major function in terms of providing life support systems, heritage value as well as risks associated with hazards. Integrated ESAs defines an area containing various ecosystems that play an important role in ensuring the well being of the environment as well as society which could be threatened by development. Three groups of ESAs are identified. These are ESA of Heritage Value, ESA associated with Hazards and ESA that is important for Life Support Systems. ESA of Heritage Value is defined as an area that has historical, cultural or scientific value. ESA associated with Hazards is defined as areas that are associated with high risks of natural or man-made hazards. ESA for Life Support Systems takes into account the present and future needs of society to ensure adequate quality of life based on resources available in the State. Integrated ESAs are useful to ensure land use that supports the aspirations of sustainable development and has the potential to enhance stakeholder participation, particularly when used in conjunction with existing land use planning mechanisms. Notwithstanding this, there are many challenges facing its application on a routine basis. These include lack of awareness and capacity, which needs to be urgently

\footnotetext{
' This paper was presented at the $20^{\text {th }}$ EAROPH World Congress and Mayors' Caucus, "Sustainable Human Settlements For A Better Quality of Life", 14-15 August 2006, Miri, Sarawak, Malaysia.

2 Datin Paduka Dr. Halimaton is a Principal Research Fellow at Institute for Environment and Development, UKM. She can be contact at halima@pkrisc.cc.ukm.my
} 
Critical Area concept has yet to be implemented officially, its effectiveness cannot be assessed.

The Department of Environment has also specified guidelines for ESAs in Malaysia to assist in the assessment of development projects (DOE 1993). The DOE defines ESAs as areas that require special attention prior to the approval of development in that particular and adjacent site. This is to ensure that the scientific, economic and aesthetic values of such a site are not threatened and that the quality of life in the present and the future is not compromised. The concept of ESAs as advocated by the DOE in principle fulfills the needs of environmental protection in the implementation of sustainable development. However, the extent of areas identified is wide and yet the number of items specified is limited. As a result, the list of ESAs as documented in the guideline is difficult to be utilised for operationalising sustainable development through existing planning and management mechanisms.

The Town and Country Planning Department of Peninsular Malaysia approaches ESAs through the land use planning perspective. A consensus was reached at the national level in 1998 regarding the scope of ESAs that is relevant to Malaysia. Ten categories of ESAs were identified and these are for Biological Diversity, Highlands and Steep Slopes, Catchment Areas, Wildlife Protection, Rivers, Wetland, Coastal Margins, Permanent Forest Reserves, Geological and Landscape Heritage and Cultural and Architectural Heritage (JPBD 1998). The Department has since prepared generic guidelines for the management of sectoral ESAs with a widened scope and recommended a consultation process to be used by State and Local Authorities in the identification and prioritization of ESAs (JPBD 2004).

\section{PERSPECTIVES ON ESAS IN THE STATE OF SELANGOR, PENINSULAR MALAYSIA}

\section{The Sectoral ESA}

In 1998, the State Government of Selangor with the support and consensus of the various technical departments attempted to harmonise various concepts and definitions relating to ESAs, which could be implemented in line with the requirements of sustainable development. The State endorsed the ten basic categories of ESAS as identified at the national level for land use planning i.e. for Biological Diversity, Highlands and Steep Slopes, Catchment Areas, Wildlife Protection, Rivers, Wetland, Coastal Margins, Permanent Forest Reserves, Geological and Landscape Heritage and Cultural and Architectural 
Heritage. In addition, it was recommended that the scope of ESAs be enlarged to incorporate aspects such as existing mining and quarrying areas, ex-mining areas, areas with potential mineral resources, waste disposal sites, aquaculture, important marine resources and agriculture.

\section{The Integrated ESA}

The State Government of Selangor also recognised the need to resolve the issue of overlapping sectoral ESAs in order to ensure its practical implementation within the planning and management process. For instance, a portion of the forest for protection of steep slopes in a catchment area may also be gazetted as a reserve for wildlife. In such a case, that particular area may be classified under three different sectoral categories i.e. ESAs for Highlands and Steep Slope, ESAs for Catchment Areas and ESAs for Wildlife Protection. It was decided that this would be overcome by integrating the various sectoral ESA (see Figure 1)

As the scope of ESAs that is required by the State involves additional categories in which development activities are conducted, there was also a need to identify the degree of sensitivity within the ESAs. This would enable the setting of limits for development activities that could be allowed in any category of ESAs. This led to the development of the Integrated ESAs.

Based on the above and upon the vision of the State Government, the concept of Sectoral ESAs was broadened to the concept of Integrated ESAs, encompassing conservation, optimum resource use and societal well-being, to meet the needs of sustainable development. In widening the scope of sectoral ESAs several limitations were identified. These include the land use conflict between the various agencies which are entrusted to manage resources on a sectoral basis, the existence of policies and management objectives which do not mutually support the overall well-being of sectoral ESAs, and the existence of ESAs which do not come under the jurisdiction of any of the existing agencies. Thus, the success of establishing Integrated ESAs as a tool to operationalise sustainable development required the commitment, cooperation and continuous networking of various implementing agencies at the State and Federal levels. This was institutionalized through the Selangor ESA Policy. 


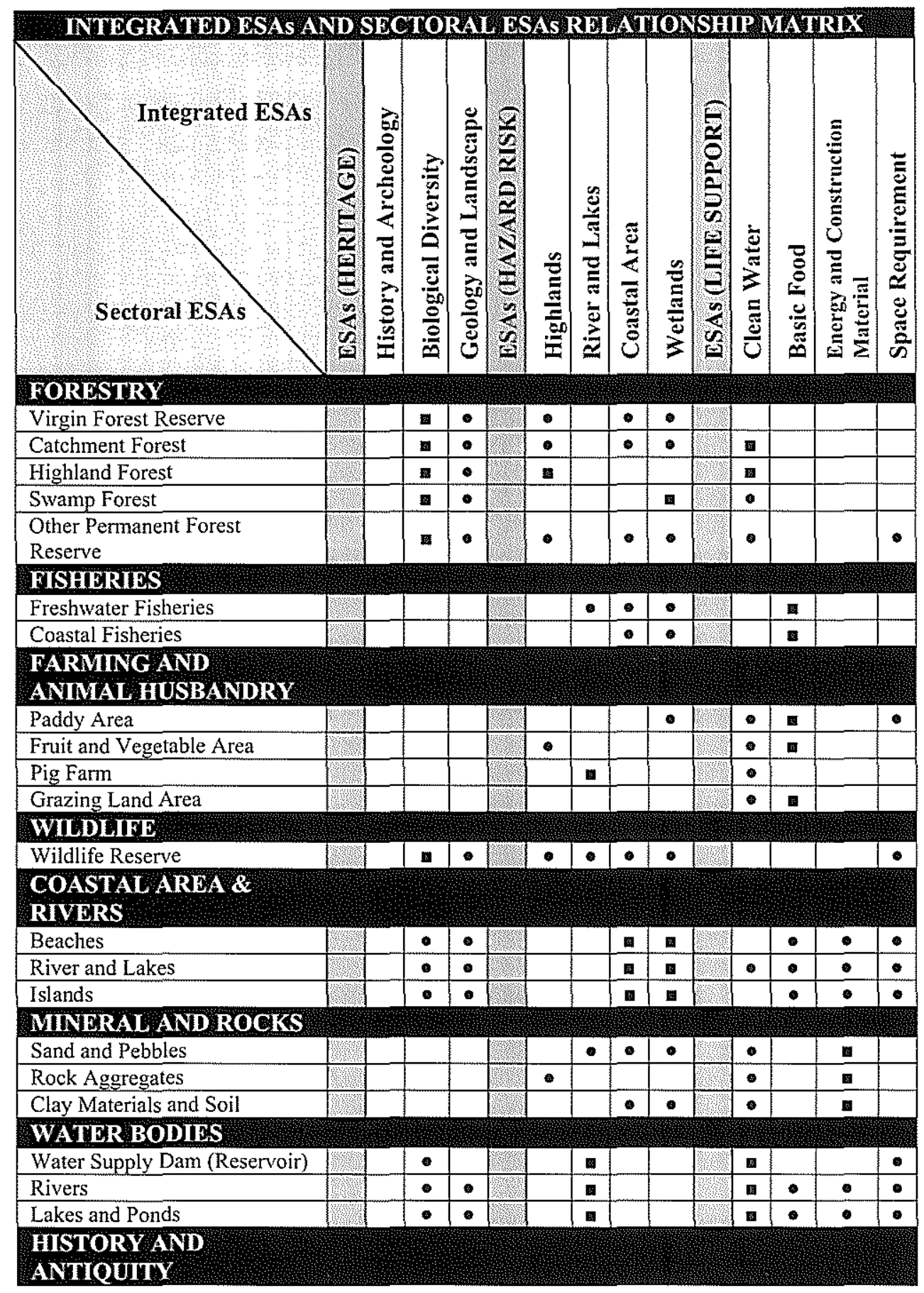




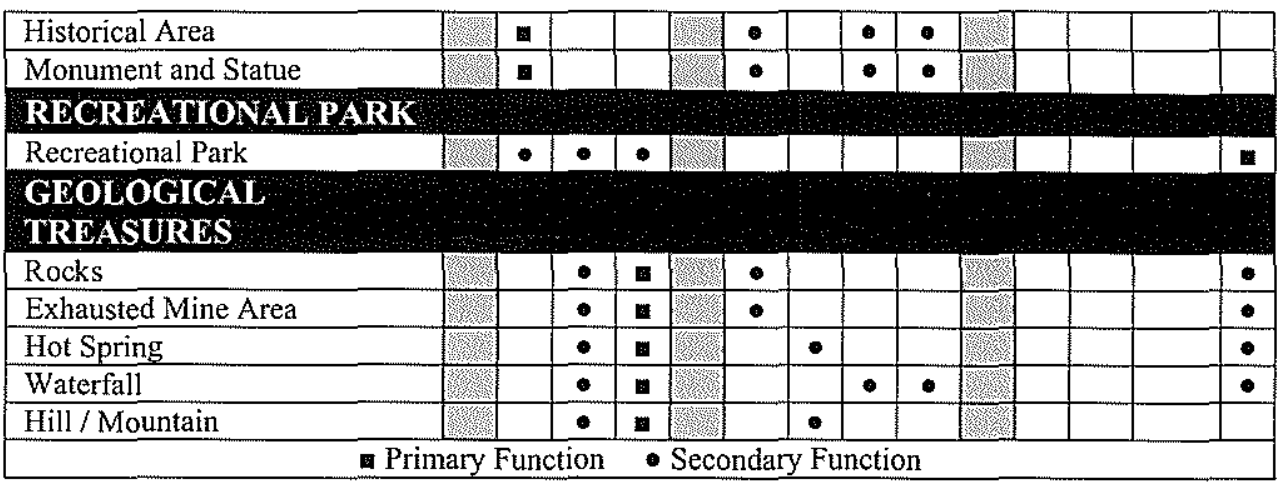

Figure 1: Matrix Depicting the Relationship of Integrated and Sectoral ESAs

\section{The Selangor ESA Policy}

The Selangor State Policy on ESAs was officially launched on 5 June 1999. The Policy takes into account the importance of an area from the perspective of the implementing government agencies and the perspective of its major function in terms of providing life support systems, heritage value as well as risks associated with hazards. The management of ESA incorporates the concept of conservation, optimisation of resource use and controlled development. The Selangor Integrated ESA concept provides a practical and effective land use planning tool to ensure environmental and societal well being.

Within the Integrated ESA framework, areas will be classified for controlled management, environmental conservation and as buffer zones. The implementation of the policy will be monitored by a Development Coordination Committee on ESAs that will define the types of development within the ESA. The State Government is presently in the process of preparing a detailed inventory of ESAs based on its degree of sensitivity. Upon completion of the inventory, an interim list of ESAs will be prepared for consultation and gazettment.

The State of Selangor would implement ESAs in two stages (GoS 1999, 2003). The first stage involves the implementation of Sectoral ESAs in the short-term. Each agency is to identify ESAs that are relevant to their sector, which could then be gazetted or managed, based on the degree of sensitivity, which would be determined. In the long-term, the State would develop and implement the concept of Integrated ESAs to resolve the overlapping sectoral ESA problem and accommodate the dynamic nature of ESAs, as a tool to operationalise sustainable development (see Figure 2). 
The ESA inventory is far from being in existence, although the target date is 2005. A start has been made with the highlands and slopes (JPBD 2005), but more needs to be done with other ESAs. The Selangor Town and Country Planning Department has a programme for this in 2006 but what is needed is for local authorities and other agencies to have their own inventories of ESAs and to gazette and enforce them. The Committee that has been established to monitor the implementation of the Selangor State Policy on ESAs is chaired by the State Secretary and its scope of work covers all types of ESA. Unfortunately all but two of the applications referred to the Committee are for development on highlands and slopes, the only other one being 'Sepang Gold Coast', which is on a coastal strip of sandy beach and mangrove swamp and a proposed development in an ex-mining lake. The approach taken by the Committee is still sectoral instead of integrated.

\section{The Elements}

Integrated ESA defines an area containing various ecosystems that play an important role in ensuring the well being of the environment as well as society, which could be threatened by development. This ESA consists of various elements and ecosystems involving various environmental functions as well as societal well being. The approach of categorising ESA should be in an integrated manner based on the perspective of sustainable development. Based on this approach, three groups of ESAs are identified. These are ESA of Heritage Value, ESA associated with Hazards and ESA that is important for Life Support Systems (GoS 1999; Ibrahim Komoo 1998). The evaluation of impacts of development in these areas should be within the framework of the natural heritage value, risk associated with various hazards and its value as a life support system. Using this approach, an ESA is categorised based on the perspective of its value and its function in the overall ecosystem.

ESA of Heritage Value is defined as an area that has historical, cultural or scientific value. Examples include historical or archaeological sites, areas with high biological and geological diversity, unique landscapes and sites of importance for education and research. Further subdivision of this ESA can be based on an assessment of its status as local, state, national or world-class heritage.

ESA Associated with Hazards is defined as areas that are associated with high risks of natural or man-made hazards. Examples include areas with problematic ground conditions for infrastructure development, areas that are prone to flooding, landslides, subsidence and erosions. A majority of these sites require 
careful planning and detailed site investigation to avoid the occurrence of human induced hazards. Included in this category are high risk areas associated with past development such as former industrial sites, mining areas and dumpsites that may be potentially hazardous to the community, should such areas be redeveloped.

Policy 1: The Selangor Darul Ehsan State Government will implement sectoral ESAs for the period of three to five years.

Policy 2: By 2005, the Selangor State Government will enforce management of integrated ESAs.

Policy 3: ESAs in Selangor are to be gazetted as areas of controlled development, buffer zones and areas for environmental conservation.

Policy 4: The Development Coordination Committee on ESAs is responsible for implementation of the Selangor Policy on ESAs.

Policy 5: The Development Coordination Committee on ESAs will decide on the type of development that can be allowed in ESAs.

Policy 6: The decision on the proposed plan for development in ESAs will be based on the Environmental Impact Assessment Report.

Policy 7: Existing laws that are relevant will be used as well as reviewed and strengthened from time to time.

Policy 8: The State Government machinery should be aware and appreciate the role of ESAs in ensuring the continuity of development in Selangor.

Policy 9: Educational and training programmes on ESAs and its management should be conducted for the public and private sectors as well as local communities.

Policy 10: The Selangor Geographic Information System (DEGIS) will contain details of ESAs and be networked to the standard database of all State and Federal agencies. 
Policy 11: The Selangor Information Technology Development Programme will take note of coordination and updating of the database at State and Federal levels.

Policy 12: The State Government will coordinate development plans for ESAs located at district borders, which come under the jurisdiction of more than one Local Authority.

Policy 13: The management of ESAs will be strengthened through research and development.

Policy 14: The State Government machinery has an appreciation for the role of ESAs in the context of life support systems, heritage conservation and risk of hazards.

Figure 2: The Selangor Policy on Environmentally Sensitive Areas (ESAs)

ESA for Life Support Systems ensures the present and future well being of society and other forms of life which is not given emphasis in many of the ESA concepts that have been promoted both at the national and international levels. ESA for Life Support Systems should be identified and classified so that the quality of life for the future generation is not compromised due to uncontrolled usage of the State's resources. Examples of areas that come under this category are sources of clean water, energy, building material, food production, settlements, parks and recreational areas. The classification of an area under this category is subjective and should be guided by existing state and national policies on development, settlement, agriculture, energy, water, natural resources and tourism.

\section{ESAS AND DEVELOPMENT}

\section{Development Principles in ESAs}

The Selangor Policy on ESAs is a very useful spatial planning tool that should be applied prior to or in conjunction with existing land use planning mechanisms at the State and local levels i.e. in the preparation or review of the State Structure Plan and Local Plans. A complete inventory of ESAs at the local level will be very useful for making decisions on applications for land use conversion or applications for planning permission, which are submitted 
routinely to State and Local Authorities. Such inventories should cover areas that are both within and around the ESAs for effective management.

Although the nature of ESAs may differ, decision making with regards to development therein should be based on three important principles. These are:

- All development in ESAs should be placed under the development category of Areas of Controlled Development;

- Development in ESAs shall not endanger the lives, result in loss of property or harm the health of local communities; and

- Development in ESAs should simultaneously enhance the socio-economic and environmental sustainability of that area.

The concept of Areas of Controlled Development is an administrative measure that was introduced in the structure plan of several districts in Selangor. In this concept, an area is divided into three main zones based on its physical and environmental characteristics as well as the types of development allowed therein. These are the restricted development zones, buffer zones and conservation zones. Development activities in these zones are administratively controlled. Such a measure can also be applied to control development in areas designated as environmentally sensitive.

\section{ESAs Inventory}

The preparation of a detailed inventory of ESAs requires information on its degree of sensitivity. Based on the Integrated ESA framework, an area can be classified into either one or more of the three categories, depending on the function it performs. Areas that are classified into two or three categories are very critical and tend to have a high degree of sensitivity towards development. Such areas are easily identified and are normally already earmarked or gazetted for conservation. For example, a catchment area located in the highlands has a life support function and also possesses a high risk for hazards, and would therefore be highly sensitive to development activities. Similarly, a forest in the highlands, which contains a variety of wildlife and plants and serves as a catchment area, is highly sensitive to development because it has a heritage value, provides a life support function and has a high risk of hazards.

All Sectoral ESAs can be reevaluated from the integrated perspective. Although an ESA may have more than one function in the integrated framework, not all these functions will have a high degree of sensitivity as illustrated in the example above. For each Sectoral ESA that is assessed, the degree of sensitivity for the functions in the integrated framework will vary. For example, a padi field would have a high degree of sensitivity with respect to its life support 
function but a low degree of sensitivity for its role as heritage value and hazards. The degree of sensitivity has to be established for each of the Sectoral ESA before it can be classified into the framework of an Integrated ESA.

\section{ESAs in Development Plans}

Development plans assist in the translation of socio-economic objectives into spatial and physical forms. The Town and Country Planning Act 1976 (Act 172) provides the legal basis for the formulation of development plans in Peninsular Malaysia. Such development plans include the National Physical Plan, State Structure Plan, Local Plan and Special Area Plan. In terms of hierarchy, the National Physical Plan is the most macro while the Special Area Plan is relatively micro.

The management of ESAs should be integrated into the process of formulating such development plans so that environmental aspects are considered in a more integrated manner. ESAs should be identified and mapped at scales that are appropriate for the various development plans. Whenever possible, the ranking and consultation process in identifying the ESA should be conducted within the process of developing or reviewing such plans. The integration of management of ESAs into development plans will at least ensure that the plans are legal although the ESAs are not gazetted as such. Strategic Environmental Assessment (SEA) and Sustainability Assessment (SA) are useful tools for assessing the sustainability of development plans at the macro level. Such tools should also be used to assess the effectiveness in managing ESAs with respect to sustainable development.

\section{ESAs and Planning Permission}

The Planning Permission process ensures that all development projects are conducted as stipulated in the development plans and other guidelines. In order to ensure that ESAs are managed effectively, reference to and consideration of ESAs should be made mandatory in the Planning Permission process. There must be mandatory requirements for references to be made on ESAs in the Development Proposal Report, which are submitted together with applications for planning permission. All development activities within or around an ESA should require an assessment similar to Environmental Impact Assessment (EIA). Detailed Environmental Impact Assessment should be mandatory if the proposed development is in an ESA and a preliminary EIA should be mandatory if the proposed development is next to an ESA. The ESAs Technical Development Committee chaired by the State Secretary vets through and advises the State Government and local planning authorities when considering 
applications for development approvals whether under the Town and Country Planning Act 1976 or the National Land Code 1965.

\section{FUTURE CHALLENGES}

Integrated ESAs is a very useful tool to ensure land use that supports the aspirations of sustainable development, particularly when used in conjunction with existing land use planning mechanisms at the State or local levels. The identification and prioritisation of ESAs at the State and local levels is important and will contribute greatly to the development of an effective National Spatial Plan. Thus, the challenge is to convince decision-makers that the availability of a complete inventory of Integrated ESAs both within and around the ESAs at the local level will be very useful for making decisions on applications for land use conversion as well as for applications for planning permission, which are submitted routinely to State and Local Authorities. In addition, sectoral resource managers also need to be convinced of the need for ESA identification to be done on a routine basis. They need to develop a systematic inventory of the resources that they manage, which is ranked by order of importance at the Federal and State levels. This information will contribute greatly to the development and review of structure and local plans at the State and Local Authority level.

In this context it is important to increase awareness and understanding as well as appreciation of the importance of having a full inventory of ESAs as well as conservation or controlled development of the ESAs by everybody, from planners and administrators to policy and decision makers at both state and local levels. It is also very important that local authorities are aware that they are the principal agencies to implement the policy for sustainable management of ESAs. For this purpose, local authorities should undertake a full inventory and gazettement of ESAs.

Integrated ESAs also has the potential to contribute to harmonisation of Federal-State issues with respect to management of land and natural resources. Making the consultation process in the identification of ESAs an explicit process, through open broad based participation of relevant stakeholders, preferably anchored by Local Authorities, and is critical in this context. It is important to ensure that the consultation process is not subsumed as part of the scientific exercise or information collection process during identification and ranking of ESAs based on degrees of sensitivity. Much work needs to be done to develop an effective consultation process, which takes into account elements 
such as conflict resolution, Delphi technique as well as economic tools such as benefit-cost analysis and willingness to pay.

Integrated ESAs can also serve as indicators of sustainable development. Its integrated nature allows it to represent many aspects of land and natural resource sustainability. This is important at the international level, when reporting progress towards sustainability to the United Nations or other Multilateral Environmental Agreements to which Malaysia is a signatory. The acreage of ESAs in any Local Authority or State also has the potential to serve as the basis for computing economic compensation, in balancing trade-offs between environment and development, between states and local authorities. These are aspects that need to be investigated in the future. Thus, there is much need for education and awareness building regarding ESAs and its current and future application in ensuring sustainable development.

The evaluation of ESAs has to be based strictly on the main function of the area, and not from the perspective of the function and objectives of the implementing agency. To enable an equitable evaluation, it is critical that a broad consultation process be institutionalised throughout the process of identification, prioritization and gazettment of the ESAs. This should involve all stakeholder groups including resource managers from Federal, State and local levels of government, the local community, private sector, non-government organizations and the scientific community. The institutionalisation of such a consultation process will provide the platform for reconciliation of both the top-down and bottom-up approaches in negotiating trade-offs in the management of ESAs, particularly with respect to competing land use. A participatory approach in the identification of ESAs as well as in planning and management of ESAs not only contributes to fulfill the need for stakeholder consultation in the progress towards sustainability, it also has great potential to enable practical implementation of the concept of intra-generational and inter-generational equity.

\section{CONCLUDING REMARKS}

An integrated ESA defines an area containing various ecosystems that play an important role in ensuring the well being of the environment as well as society, which could be threatened by development. Three groups of ESAs are identified. These are ESA of Heritage Value, ESA associated with Hazards and ESA that is important for Life Support Systems. The evaluation of impacts of development in these areas should be within the framework of the natural heritage value, risk associated with various hazards and its value as a life 
support system. Using this approach, an. ESA is categorised based on the perspective of its value and its function in the overall ecosystem.

Integrated ESAs are useful to ensure land use that supports the aspirations of sustainable development and has the potential to enhance stakeholder participation, particularly when used in conjunction with existing land use planning mechanisms. Notwithstanding this, there are many challenges facing its application on a routine basis. These include lack of awareness and capacity, which need to be urgently addressed. More work is also required to develop complete inventory of Integrated ESAs both within and around the ESAs, particularly at the local level and for ranking of resources according to their importance. In addition, there is a need to develop an effective consultation process, to be an explicit part in developing Integrated ESA, to be anchored by Local Authorities and involving all relevant stakeholders.

Integrated ESAs allows for the best possible land use for a given area by taking into account environmental, resource base and socio-economic factors. It also facilitates allocation of land that provides the greatest long-term and equitable benefit in line with the broad objective of sustainable development.

\section{ACKNOWLEDGEMENTS}

The authors wish to thank the research team from Universiti Kebangsaan Malaysia for providing continuos support in the development of the ESA concept. The State Government of Selangor Darul Ehsan is acknowledged for funding the Projects on Strategies for Sustainable Development and Agenda 21 Selangor (1999-2002) and Planning Guidelines for Development in Highland ESAs of Selangor (2005), implemented by the Town and Country Planning Department of Selangor, with technical assistance from the Institute for Environment and Development (LESTARI), Universiti Kebangsaan Malaysia.

\section{REFERENCES}

DOE 1993. Buku Panduan Kawasan Sensitif Alam Sekitar. JAS Kementerian Sains, Teknologi dan Alam Sekitar, Malaysia.

EPU 1993. Malaysian National Conservation Strategy-Towards Sustainable Development. Vol. 3: Critical Areas. EPU Prime Minister's Department, Malaysia. 
Government of Selangor (GoS) 1999. Strategi Pembangunan Mampan dan Agenda 21 Selangor: Kawasan Sensitif Alam Sekitar. Institut Alam Sekitar dan Pembangunan (LESTARI), Bangi.

Government of Selangor (GoS) 2003. Agenda 21 Selangor-Selangor's Commitment to Sustainable Development. Town and Country Planning Department of Selangor, Shah Alam.

Hyams, E. 1952. Soil and civilization. Thames and Hudson, London.

Ibrahim Komoo 1998. Kawasan Sensitif Alam Sekitar Selangor. Dialog Kawasan Sensitif Alam Sekitar Negeri Selangor. 14 Mei 1998 JPBD Negeri Selangor, Shah Alam Selangor.

Jabatan Perancangan Bandar dan Desa (JPBD) 1998. Kawasan Sensitif Alam Sekitar [Environmentally Sensitive Areas]. Rumusan Bengkel KSAS JPBD-Semenanjung Malaysia, 22-23 April 1998, Kuala Lumpur.

Jabatan Perancangan Bandar dan Desa (JPBD) 2004. Guidelines for the Conservation and Development of Environmentally Sensitive Areas and Its Surroundings. Draft Final Report Prepared by PAG Consult Sdn. Bhd. for JPBD-Semenanjung Malaysia, Kuala Lumpur.

Jabatan Perancangan Bandar dan Desa Selangor Darul Ehsan (JPBD) 2005. Garispanduan Pembangunan KSAS Perbukitan dan Tanah Tinggi Selangor. Draft Final Report Prepared by Institute for Environment and Development (LESTARI), UKM for JPBD-Selangor, Shah Alam.

MAFF 1989. Environmentally Sensitive Areas: First Annual Report as required Under Section 18(8) of the Agriculture Act 198, Ministry of Agriculture, Fisheries and Food, London.

Watson W.D., Tully, J.K., Moser, E., Dee D.P., Bryant K. Schall R. and Allan H.A. 1995. Coal Resources in Environmentally Sensitive Lands under Federal Management. Open-File Report 95-631. US Geological Survey, USA. 